\title{
A new Tapinocyba Simon, 1884 from southern China (Aranei: Linyphiidae)
}

\author{
Новый виА Тapinocyba Simon, 1884 из Южкного Китая \\ (Aranei: Linyphiidae)
}

\author{
A.V. Tanasevitch \\ A.B. Танасевич \\ A.N. Severtsov Institute of Ecology and Evolution, Russian Academy of Sciences, Leninsky prospekt 33, Moscow 119071, Russia. \\ E-mail: tanasevitch@gmail.com \\ Институт проблем экологии и эволюции им. А.Н. Северцова РАН, Ленинский проспект 33, Москва 119071, Россия.
}

KEY WORDS: taxonomy, spiders, Erigoninae, new species.

КЛЮЧЕВЫЕ СЛОВА: таксономия, пауки, Erigoninae, новый вид.

ABSTRACT. A new species, Tapinocyba emei sp.n., is described on the basis of males from the Sichuan Province, China. The new species is similar to the Taiwan T. formosa Tanasevitch, 2011, but is clearly distinguished by the elongated radix, claw-shaped embolus, as well as by the shape of the palpal tibia.

How to cite this article: Tanasevitch A.V. 2018. A new Tapinocyba Simon, 1884 from southern China (Aranei: Linyphiidae) // Arthropoda Selecta. Vol.27. No.2. P.169-171. doi: 10.15298/arthsel. 27.2.08

РЕЗЮМЕ. Новый вид Tapinocyba emei sp.n. описан по самцам из провинции Сычуань, Китай. Вид близок к T. formosa Tanasevitch, 2011, известному с Тайваня, но хорошо отличается вытянутым радиксом, когтевидным эмболюсом, а также формой голени пальпы.

\section{Introduction}

At present, the Holarctic genus Tapinocyba Simon, 1884 contains 37 species [World Spider catalog, 2018]. Most occur in the West Palaearctic, largely Europe, and only four species are distributed in Asia east of the Yenisei biogeographical border: T. formosa Tanasevitch, 2011, from Taiwan [Tanasevitch, 2011], $T$. kolymensis Eskov, 1989, widespread in the Russian Far East [Mikhailov, 2013] and China [Song et al., 1999]; two species, T. silvicultrix Saito, 1980 and T. suganamii Saito et Ono, 2001, from Japan [Ono et al., 2009]. The new species taken from the Sichuan Province, China has recently been found in the spider collection of the Senckenberg Museum, Frankfurt am Main, Germany (SMF). The description of this species is given below.

\section{Material and methods}

This paper is based on spider material collected from the Sichuan Province, China by Peter Jäger and kept at the SMF.

Specimens preserved in $70 \%$ ethanol were studied using a MBS-9 stereo microscope and a Wild compound microscope. A Levenhuk C-800 digital camera was used for the execution of some drawings. Images of multiple focal sections were combined using Helicon Focus image stacking software. The chaetotaxy is given in a formula, i.e, 1.1.1.1, which refers to the number of dorsal spines on tibiae I-IV. The sequence of leg segment measurements is as follows: femur + patella + tibia + metatarsus + tarsus. All measurements are given in millimeters. Scale lines in the figures correspond to $0.1 \mathrm{~mm}$ or $0.5 \mathrm{~mm}$. Figure numbers are given above the scale lines, the distance below.

The terminology of copulatory organs mainly follows that of Merrett [1963], Holm [1979] and Hormiga [2000].

The following abbreviations are used in the text and figures: a.s.1. — above sea level; DSA — distal suprategular apophysis sensu Hormiga [2000]; E embolus; R - radix; Pr — protegulum sensu Holm [1979]; TmI - position of trichobothrium on metatarsus I.

\section{Description}

\section{Tapinocyba emei sp.n.} Figs $1-5$.

HOLOTYPE o' (SMF), CHINA, Sichuan Province, Emei, Mts Emei Shan, Wannian Temple, on clay slope, $1000 \mathrm{~m}$ a.s.1., $29^{\circ} 4.88^{\prime} \mathrm{N}$ $103^{\circ} 22.940^{\prime}$ E, 20.III.1999, leg. P. Jäger.

PARATYPES. $2 \sigma^{7} \sigma^{7}$ (SMF), collected together with holotype; $1 \sigma^{7}$ (SMF), Wannian Temple, $29^{\circ} 4.88^{\prime} \mathrm{N} 103^{\circ} 22.940^{\prime} \mathrm{E}, 21-$ 30.III.1999, leg. P. Jäger. 

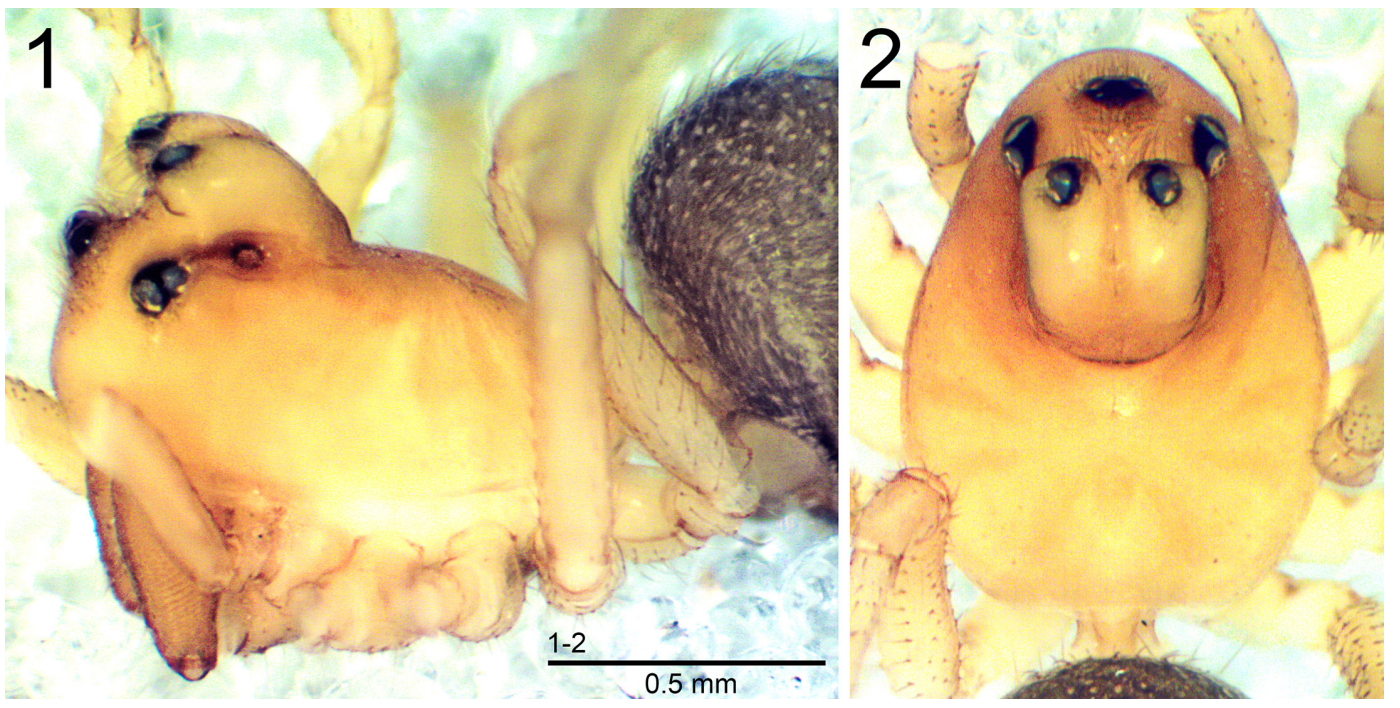

Figs 1, 2. Photographs of Tapinocyba emei sp.n., o paratype. 1,2 - body, anterolateral and dorsal view, respectively. Рис. 1, 2. Фотография Tapinocyba етеi sp.n., о п паратип. 1, 2 - тело, вид с боку и спереди, вид сверху, соответственно.

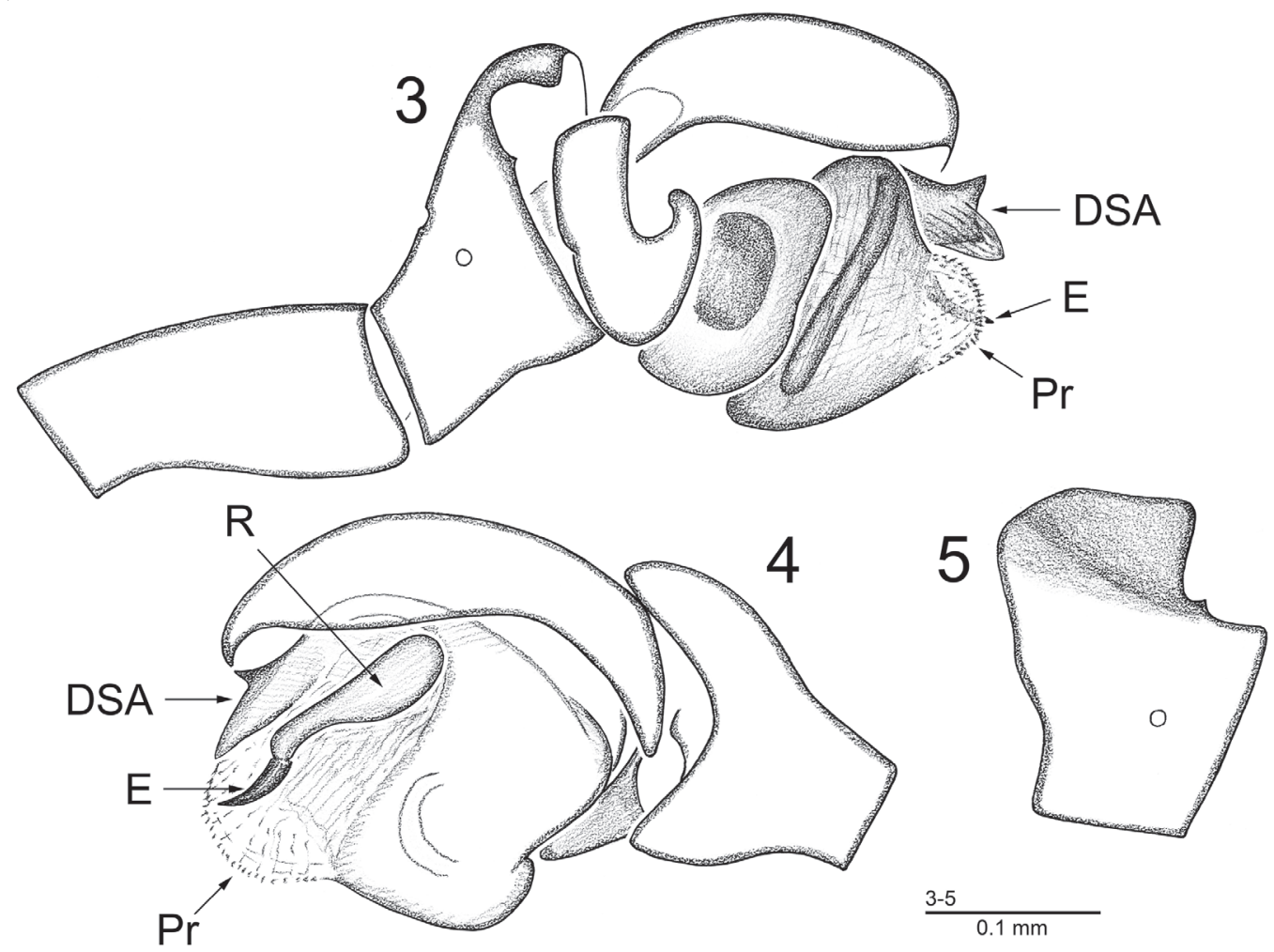

Figs 3-5. Tapinocyba emei sp.n., O paratype. 3, 4- right palp, retrolateral and prolateral view, respectively; 5 - palpal tibia, dorsal view.

Рис. 3-5. Tapinocyba emei sp.n., O паратип. 3, 4- правая пальпа, ретролатерально и пролатерально, соответственно; 5 голень пальпы, вид сверху.

NAME. The specific name is a noun in apposition referring to the country of origin, the Mts Emei Shan, China.

DIAGNOSIS. The new species is most similar to the Taiwan $T$. formosa, but is clearly distinguished by the elongated radix, claw-shaped embolus, as well as by the shape of the palpal tibia.

DESCRIPTION. Male holotype. Total length 2.12. Carapace modified as shown in Figs 1-2; 1.05 long, 0.75 wide, pale brown. Head part of carapace with a 
bipartite elevation, each part carrying a posterior median eye. Sulci presence, eyes not enlarged, normal. Chelicerae 0.35 long, mastidion absent. Legs pale yellow. Leg I 2.53 long $(0.75+0.25+0.63+0.50+0.40)$, IV long $(0.75+0.25+0.65+0.53+0.40)$. Chaetotaxy 1.1.1.1, length of spines about $0.5-1$ diameter of segment. Metatarsus I-III each with a trichobothrium. TmI 0.44. Palp (Figs 3-5): Patella elongated. Tibia with a notch on retrolateral side. Paracymbium U-shaped. Tegulum with a protegulum. Distal suprategular apophysis short, with a small, sharp denticle. Median membrane very small, poorly visible. Radix elongated, narrow. Embolus relatively short, claw-shaped. Abdomen 1.10 long, 0.80 wide, grey.

Female unknown.

DISTRIBUTION. Known only from the type locality in Mts Emei Shan, Sichuan, China.

ACKNOWLEDGEMENTS. I am greatly indebted to Peter Jäger (SMF) whose material was used in the present study. I also thank Sergei I. Golovatch (Moscow) who kindly checked the English of an advanced draft.

\section{References}

Holm Å. 1979. A taxonomic study of European and East African species of the genera Pelecopsis and Trichopterna (Araneae, Linyphiidae), with descriptions of a new genus and two new species of Pelecopsis from Kenya // Zoologica Scripta. Vol.8. P.255-278.

Hormiga G. 2000. Higher level phylogenetics of erigonine spiders (Araneae, Linyphiidae, Erigoninae) // Smithsonian Contributions to Zoology. No.609. P.1-160.

Merrett P. 1963. The palpus of male spiders of the family Linyphiidae // Proceedings of the Zoological Society of London. Vol.140. P.347-467.

Mikhailov K.G. 2013. The spiders (Arachnida: Aranei) of Russia and adjacent countries: a non-annotated checklist // Arthropoda Selecta. Supplement. Vol.3. P.1-262.

Ono H., Matsuda M., Saito H. 2009. Linyphiidae, Pimoidae // Ono H. (ed.). The Spiders of Japan with keys to the families and genera and illustrations of the species. Kanagawa: Tokai University Press. P.253-344.

Song D.X., Zhu M.S., Chen J. 1999. The Spiders of China. Shijiazhuang: Hebei University of Science and Technology Publishing House. 640 pp.

Tanasevitch A.V. 2011. On some linyphiid spiders from Taiwan (Araneae: Linyphiidae) // Zootaxa. Vol.3114. P.31-39.

World Spider Catalog 2018. World Spider Catalog, version 19.0. Natural History Museum Bern. Online at http://wsc.nmbe.ch (accessed in March, 2018).

Responsible editor K.G. Mikhailov 